\title{
Analysis of baseline hepatitis B virus DNA levels in chronic hepatitis B patients with non-hematological malignancies prior to the initiation of cancer chemotherapy
}

\author{
SHIH-HAO YOUNG ${ }^{1,3}$, TIEN-HSIN WEI ${ }^{1,3}$, CHUNG-CHI LIN ${ }^{2,3}$, CHI-JEN CHU ${ }^{1,3}$, FA-YAUH LEE ${ }^{1,3}$, MAY-ING YU ${ }^{1}$, \\ REI-HWA LU ${ }^{1}$, CHIAO-YU CHANG ${ }^{1}$, PEI-LING YANG ${ }^{1}$, MEI-HUI WANG ${ }^{1}$ and HAN-CHIEH LIN ${ }^{1,3}$ \\ ${ }^{1}$ Division of Gastroenterology and Hepatology, Department of Medicine; ${ }^{2}$ Healthcare and Services Center, \\ Taipei Veterans General Hospital; ${ }^{3}$ National Yang-Ming University School of Medicine, Taipei 11217, Taiwan, R.O.C.
}

Received August 25, 2015; Accepted April 1, 2016

DOI: $10.3892 /$ mco. 2016.857

\begin{abstract}
Reactivation of hepatitis B virus (HBV) infection is common ( $20-50 \%)$ during cancer chemotherapy. Baseline $\mathrm{HBV}$ replication status is an important risk factor for $\mathrm{HBV}$ reactivation. To date, data on the baseline HBV DNA level for chronic hepatitis B (CHB) patients prior to chemotherapy, particularly for non-hematological malignancies, are limited. A total of 105 consecutive CHB patients with solid tumors who received prophylactic antiviral therapy prior to chemotherapy from November, 2011 to December, 2014, were enrolled in this study. The patients' tumors included: Breast cancer $(37.1 \%)$, lung cancer $(18.1 \%)$, colon cancer $(17.1 \%)$, head and neck cancer $(10.5 \%)$, other gastrointestinal tract malignancies $(8.6 \%)$, gynecological cancer $(4.8 \%)$ and others $(3.8 \%)$. The mean age of the enrolled patients was $55.2 \pm 1.1$ years, 48 of the patients were male, 3 were hepatitis B e antigen-positive, and $26.7 \%$ had abnormal alanine aminotransferase (ALT) levels at baseline. The median HBV DNA level measured by quantitative polymerase chain reaction assay prior to chemotherapy was 3.30 $\log _{10} \mathrm{IU} / \mathrm{ml}$ and $49.5 \%$ of the enrolled patients had a baseline HBV DNA level $>2,000 \mathrm{IU} / \mathrm{ml}$. A wide range of HBV distribution was found: $<20 \mathrm{IU} / \mathrm{ml}(15.2 \%), 20 \leq \mathrm{DNA}<2,000 \mathrm{IU} / \mathrm{ml}$ $(35.3 \%), \quad 2,000 \leq \mathrm{DNA}<20,000 \mathrm{IU} / \mathrm{ml} \quad(26.6 \%)$, $20,000 \leq \mathrm{DNA}<10^{6} \mathrm{IU} / \mathrm{ml}(17.2 \%)$ and $<10^{6} \mathrm{IU} / \mathrm{ml}(5.7 \%)$. Age
\end{abstract}

Correspondence to: Dr Chi-Jen Chu, Division of Gastroenterology and Hepatology, Department of Medicine, Taipei Veterans General Hospital, No. 201, Sec. 2, Shih-Pai Road, Taipei 11217, Taiwan, R.O.C. E-mail: cjchu@vghtpe.gov.tw

Abbreviations: AASLD, American Association for the Study of Liver Diseases; ALT, alanine aminotransferase; CHB, chronic hepatitis B; DNA, deoxyribonucleic acid; $\mathrm{HBeAg}$, hepatitis $\mathrm{B}$ e antigen; HBsAg, hepatitis B surface antigen; HBV, hepatitis B virus; PCR, polymerase chain reaction

Key words: chemotherapy, hepatitis B virus DNA level, hepatitis B virus reactivation, non-hematological malignancies, quantitative hepatitis B surface antigen level, quantitative polymerase chain reaction and baseline ALT level were not strongly associated with virological activity. The mean HBV DNA and the percentage of patients with HBV DNA >2,000 IU/ml were comparable between different cancer groups. Quantitative HBsAg level was a major determinant of baseline HBV DNA, and a significant correlation was noted between $\log _{10}$ hepatitis B surface antigen and $\log _{10}$ HBV DNA levels $(\gamma=0.641, P<0.001)$. Our study demonstrated a wide distribution of baseline HBV DNA level among CHB patients diagnosed with non-hematological malignancies. Of note, approximately half of the patients (i.e., those with HBV DNA $>2,000 \mathrm{IU} / \mathrm{ml}$ ) had a higher risk of $\mathrm{HBV}$ reactivation if no appropriate antiviral prophylaxis was undertaken.

\section{Introduction}

Reactivation of hepatitis B virus (HBV) replication with an increase in serum HBV DNA and alanine aminotransferase (ALT) level has been reported in 20-50\% of chronic hepatitis $\mathrm{B}(\mathrm{CHB})$ carriers undergoing immunosuppressive or cancer chemotherapy (1-4). A study on lymphoma patients (1) demonstrated that hepatitis caused by HBV reactivation usually occurred after two or three courses of chemotherapy; however, it may develop at any time during or after immunosuppressive therapy. The clinical presentation of $\mathrm{HBV}$ reactivation may vary, ranging from symptomatic, mild hepatitis to hepatic failure or death (4-6). As previously described, the risk of $\mathrm{HBV}$ reactivation and prognosis are determined by host factors, underlying disease, baseline HBV status and the intensity of immunosuppression (1,2,7-12).

Regarding the significance of baseline HBV replication status, as previously described (6), chronic HBV-infected patients with positive hepatitis B surface antigen (HBsAg) have a higher risk of reactivation following immunosuppressive or cancer chemotherapy compared with patients with resolved $\mathrm{HBV}$ infection (i.e., anti-HBc-positive, HBsAg-negative). For patients with positive HBsAg, a higher HBV DNA level prior to therapy $(>2,000 \mathrm{IU} / \mathrm{ml})$ has been demonstrated to be an important risk factor for $\mathrm{HBV}$ reactivation compared with those having lower HBV DNA levels $(11,12)$. The majority of patients with resolved $\mathrm{HBV}$ infection have undetectable serum 
HBV DNA levels; however, the risk of HBV reactivation remains higher for the minority with detectable HBV DNA at baseline $(13,14)$.

To prevent HBV reactivation during cancer chemotherapy, clinical studies, including randomized controlled trials, demonstrated that prophylactic use of an oral antiviral agent, mainly lamivudine, may reduce the rate of HBV reactivation and the severity of associated hepatitis flares and mortality (15-19). According to the 2009 American Association for the Study of Liver Diseases (AASLD) CHB practice guideline update (20), patients with a high baseline HBV DNA $(>2,000 \mathrm{IU} / \mathrm{ml})$ level must continue treatment until they reach treatment endpoints as in immunocompetent patients. In addition, oral antiviral agents with high potency and low resistance profile, such as entecavir or tenofovir, were preferred if a longer duration of treatment is anticipated, or in patients with baseline HBV DNA $>2,000 \mathrm{IU} / \mathrm{ml}$ to avoid selection of drug-resistant mutations. Therefore, measurement of serum quantitative HBV DNA level was mandatory prior to initiation of chemotherapy.

To date, the data on baseline HBV DNA level prior to the initiation of cancer chemotherapy, particularly in CHB patients with non-hematological malignancies, are limited. Therefore, this retrospective study was conducted to address this issue. In addition, factors associated with virological activities were investigated.

\section{Patients and methods}

Eligible candidates. This study was a retrospective, single-center, data collection study. From November, 2011 to December, 2014, a total of 105 consecutive CHB carriers with non-hematological malignancies who received prophylactic oral antiviral agents prior to the initiation of chemotherapy were enrolled by the investigators for analysis. CHB carrier status was defined as follows: Positive HBsAg for $>6$ months preceding entry into the study, with either positive or negative hepatitis B e antigen ( $\mathrm{HBeAg}$ ). Patients were excluded if they were already on antiviral therapy for $\mathrm{CHB}$, or had evidence of coinfection with hepatitis $\mathrm{C}$ virus, hepatitis $\mathrm{D}$ virus or human immunodeficiency virus. After November, 2009, the National Health Insurance Administration, Ministry of Health and Welfare of the Taiwanese government reimbursed the cost of prophylactic oral antiviral agent for $\mathrm{CHB}$ carriers to prevent $\mathrm{HBV}$ reactivation during cancer chemotherapy. In the present study, 6 patients received prophylactic therapy with lamivudine (100 mg/day) and the remaining 99 patients were treated with entecavir $(0.5 \mathrm{mg} /$ day $)$. Prophylactic antiviral agent was started within 1 week prior to the initiation of chemotherapy and was maintained for $\geq 6$ months after completion of cancer chemotherapy. The present study was performed in accordance with the principles of Good Clinical Practice, the principles of the Declaration of Helsinki and its appendices, and local and national laws. Written informed consent was obtained from all participants.

Study design and laboratory examinations. Demographic data and clinical information on the enrolled patients, including cancer diagnosis, staging and chemotherapy regimen, were collected. Biochemical and hematological testing were performed by commercially available assays. Hepatitis B serological markers (HBeAg and anti-HBe) were tested using commercially available enzyme-linked immunosorbent assay kits. Quantitative HBsAg levels were determined by the ARCHITECT HBsAg assay (Abbott Laboratories, Abbott Park, IL, USA), with a sensitivity of $0.05 \mathrm{IU} / \mathrm{ml}$ (21). Serum quantitative HBV DNA levels prior to the initiation of chemotherapy was measured by commercially available quantitative polymerase chain reaction (PCR) assay $\left(\mathrm{COBAS}^{\circledR}\right.$ AmpliPrep/COBAS ${ }^{\circledR}$ TaqMan ${ }^{\circledR}$ HBV Test, Roche Molecular Diagnostics, Basel, Switzerland), with a lower detection limit of $20 \mathrm{IU} / \mathrm{ml}(22)$.

Statistical analyses. The results are expressed as mean \pm standard error of the mean. Data were analyzed using the SPSS software package, version 12.0 (SPSS Inc., Chicago, IL, USA). Statistical analyses were performed using Chi-square and Fisher's exact tests for categorical variables. Independent t-tests were used for continuous variables. The association between HBV DNA level (in $\log _{10} \mathrm{IU} / \mathrm{ml}$ ) and serum quantitative HBsAg level (in $\log _{10} \mathrm{IU} / \mathrm{ml}$ ) were determined by the Pearson's correlation model. The results were considered statistically significant at $\mathrm{P}<0.05$.

\section{Results}

Baseline characteristics of enrolled patients (Table I). The mean age of the enrolled patients was 55.2 \pm 1.1 years; 48 of the patients were male; 3 of the patients were HBeAg-positive, and $27.6 \%$ had abnormal ALT levels at baseline (>40 U/1). The patient composition by diagnosis was as follows: Breast cancer $(37.1 \%)$, lung cancer (18.1\%), colon cancer $(17.1 \%)$, head and neck cancer $(10.5 \%)$, other gastrointestinal tract malignancies $(8.6 \%)$, gynecological cancer (4.8\%) and others (malignant thymoma, melanoma and osteosarcoma) (3.8\%).

Distribution of baseline HBV DNA levels prior to the initiation of chemotherapy. The median HBV DNA level prior to chemotherapy was $3.30 \log _{10} \mathrm{IU} / \mathrm{ml}$. The distribution of HBV DNA levels were as follows: Undetectable by PCR, i.e., $<20 \mathrm{IU} / \mathrm{ml}(15.2 \%)$; $20 \leq$ DNA $<2,000 \mathrm{IU} / \mathrm{ml}(35.3 \%) ; 2,000 \leq \mathrm{DNA}<20,000 \mathrm{IU} / \mathrm{ml}$ (26.6\%); 20,000 $\leq \mathrm{DNA}<10^{6} \mathrm{IU} / \mathrm{ml}(17.2 \%)$; and $\geq 10^{6} \mathrm{IU} / \mathrm{ml}$ (5.7\%) (Table II). A total of $49.5 \%$ of the enrolled patients had baseline HBV DNA levels of $>2,000 \mathrm{IU} / \mathrm{ml}$.

Comparisons between patients with baseline HBV DNA levels $\leq 2,000 \mathrm{IU} / \mathrm{ml}$ and $>2,000 \mathrm{IU} / \mathrm{ml}$ (Table III). Age, gender and hematological data were not significantly associated with virological activity. Patients with a baseline HBV DNA level of $>2,000 \mathrm{IU} / \mathrm{ml}$ tended to have a higher mean level of ALT and aspartate aminotransferase; however, the difference did not reach significance. As compared with patients with baseline normal ALT, a higher percentage of patients with abnormal baseline ALT had HBV DNA level >2,000 IU/ml (65.5 vs. $44.7 \%$, respectively) but the difference was not statistically significant $(\mathrm{P}=0.057)$. The mean serum quantitative HBV DNA level was comparable between patients diagnosed with breast cancer $\left(3.16 \pm 0.24 \log _{10} \mathrm{IU} / \mathrm{ml}\right)$, colon cancer (3.14 $\left.\pm 0.45 \log _{10} \mathrm{IU} / \mathrm{ml}\right)$, lung cancer $\left(3.20 \pm 0.33 \log _{10} \mathrm{IU} / \mathrm{ml}\right)$ and other types of camcer $\left(3.68 \pm 0.28 \log _{10} \mathrm{IU} / \mathrm{ml}\right)$. The percentage of patients with HBV DNA level $>2,000 \mathrm{IU} / \mathrm{ml}$ 
Table I. Baseline characteristics of enrolled patients $(n=105)$.

\begin{tabular}{|c|c|}
\hline Characteristics & No. $(\%)$ \\
\hline Age, years (mean \pm SEM) & $55.2 \pm 1.1$ \\
\hline Gender, male/female & $48 / 57(46 / 54)$ \\
\hline \multicolumn{2}{|l|}{ Diagnosis } \\
\hline Breast cancer & $39(37.1)$ \\
\hline Lung cancer & $19(18.1)$ \\
\hline Colon cancer & $18(17.1)$ \\
\hline Head and neck cancer & $11(10.5)$ \\
\hline Other gastrointestinal tract cancers & $9(8.6)$ \\
\hline Gynecological cancer & $5(4.8)$ \\
\hline Others & $4(3.8)$ \\
\hline HBeAg-positive status & $3(2.9)$ \\
\hline ALT, U/1 (mean \pm SEM) & $37.7 \pm 4.3$ \\
\hline AST, U/1 (mean \pm SEM) & $35.7 \pm 5.0$ \\
\hline Total bilirubin, mg/dl (mean \pm SEM) & $0.81 \pm 0.15$ \\
\hline Creatinine, mg/dl (mean \pm SEM) & $0.78 \pm 0.02$ \\
\hline $\mathrm{WBC}$ count $/ \mathrm{mm}^{3}($ mean $\pm \mathrm{SEM})$ & $6935 \pm 289$ \\
\hline $\mathrm{Hgb}, \mathrm{g} / \mathrm{dl}($ mean $\pm \mathrm{SEM})$ & $12.28 \pm 0.19$ \\
\hline PLT count $x 1,000 / \mathrm{mm}^{3}($ mean $\pm \mathrm{SEM})$ & $228.4 \pm 8.2$ \\
\hline
\end{tabular}

SEM, standard error of the mean; HBeAg, hepatitis B e antigen; ALT, alanine aminotransferase; AST, aspartate aminotransferase; WBC, white blood cell; Hgb, hemoglobin; PLT, platelet.

Table II. Distribution of baseline HBV DNA levels prior to the initiation of chemotherapy.

\begin{tabular}{lc}
\hline HBV DNA level $(\mathrm{IU} / \mathrm{ml})$ & No. $(\%)$ \\
\hline Undetectable by quantitative PCR $(<20)$ & $16(15.2)$ \\
$20 \leq \mathrm{DNA}<2,000$ & $37(35.3)$ \\
$2,000 \leq \mathrm{DNA}<20,000$ & $28(26.6)$ \\
$20,000 \leq \mathrm{DNA}<10^{6}$ & $18(17.2)$ \\
$\geq 10^{6}$ & $6(5.7)$ \\
\hline
\end{tabular}

$\mathrm{HBV}$, hepatitis B virus; PCR, polymerase chain reaction.

were similar among these groups. All 3 patients with positive HBeAg had HBV DNA levels $>2,000 \mathrm{IU} / \mathrm{ml}$. The quantitative HBsAg level was a major determinant of baseline HBV DNA level: $38 / 51(74.5 \%)$ patients with $\mathrm{HBsAg} \geq 250 \mathrm{IU} / \mathrm{ml}$ had a HBV DNA level $>2,000 \mathrm{IU} / \mathrm{ml}$, as compared with patients with HBsAg <250 IU/ml $(27.8 \%)(\mathrm{P}<0.001)$. In addition, 20/23 (87.0\%) patients with $\mathrm{HBsAg}>1,000 \mathrm{IU} / \mathrm{ml}$ had a HBV DNA level $>2,000 \mathrm{IU} / \mathrm{ml}$, whereas only $20 \%$ (8/40) with HBsAg <100 IU/ml had HBV DNA > 2,000 IU/ml.

Correlation between quantitative HBsAg and HBV DNA levels. To investigate the correlation between quantitative HBsAg and HBV DNA levels, these data were transformed into $\log _{10} \mathrm{IU} / \mathrm{ml}$ and a significant correlation was observed between $\log _{10} \mathrm{HBsAg}$ and $\log _{10} \mathrm{HBV}$ DNA levels (correlation coefficient $\gamma=0.641, \mathrm{P}<0.001)$.

\section{Discussion}

HBV reactivation caused by cancer chemotherapy has been extensively investigated in patients with lymphoma. The earliest prospective study from Hong Kong (1) enrolled 100 patients for analysis and the serum HBV DNA levels were measured regularly prior to and during chemotherapy. At baseline, 27 of the patients were chronic HBV carriers (i.e., HBsAg-positive), 51 belonged to the resolved HBV infection group (i.e., anti-HBc-positive and HBsAg-negative) and 22 patients did not exhibit evidence of previous HBV infection. The results demonstrated that hepatitis associated with HBV reactivation developed in 48, 4 and $0 \%$ of the patients, respectively. In addition, hepatic failure due to $\mathrm{HBV}$ reactivation occurred in 7,2 and $0 \%$ of the patients, respectively (1). The increased risk of HBV carriers may be explained by the necessity of intensive chemotherapy for lymphoma and the addition of corticosteroids, which exert a potent immunosuppressive effect, and the direct stimulation of viral replication via glucocorticoid-responsive elements in the HBV genome (23).

HBV reactivation may also occur in patients receiving chemotherapy for solid tumors, the targeted population of the present study. Initially, the majority of the reports were based on the findings from patients treated for breast cancer $(7,24)$. However, later reports suggested that $\mathrm{HBV}$ reactivation by chemotherapy developed in a wide range of solid tumors, including colon, lung and head and neck cancers $(2,8)$. In a study that included $63 \mathrm{HBsAg}$-positive patients with solid tumors (2), the incidence of $\mathrm{HBV}$ reactivation was reported to be $\sim 10-38 \%$ among different diagnoses. A higher incidence of reactivation has been reported in patients with breast cancer (41\%) compared with that in patients with other solid tumors (7-29\%) (8); the concomitant use of anthracyclines has been suggested to be one of the possible underlying mechanisms $(25,26)$.

To the best of our knowledge, this is the first study to evaluate the baseline HBV replication status prior to the initiation of chemotherapy for consecutive $\mathrm{CHB}$ patients with non-hematological malignancies. Interestingly, a wide variation of baseline HBV DNA distribution was observed. Approximately $15 \%$ of the enrolled CHB-infected patients had undetectable HBV DNA by quantitative PCR prior to the initiation of cancer chemotherapy. By contrast, a total of $49.5 \%$ of the enrolled patients with a baseline HBV DNA level of $>2,000 \mathrm{IU} / \mathrm{ml}$, were at risk for HBV reactivation induced by immunosuppression $(11,12)$. Our results supported the significance of universal screening prior to initiation of cancer chemotherapy recommended by the US Centers for Disease Control and Prevention (27), the European Association for the Study of the Liver (28) and the Asian-Pacific Association for the Study of the Liver (29), particularly in highly endemic area of HBV infection, such as Taiwan. As several patients are unaware of their HBV infection status, the purpose of HBV screening is to identify patients who are infected and who may benefit from preventative antiviral therapy or close monitoring.

Regarding the selection of oral antiviral agents, the majority of published studies investigating the efficacy of 
Table III. Comparison of patient characteristics between baseline HBV DNA levels $\leq 2,000(\mathrm{n}=52)$ and $>2,000 \mathrm{IU} / \mathrm{ml}(\mathrm{n}=53)$.

\begin{tabular}{|c|c|c|c|}
\hline \multirow[b]{2}{*}{ Characteristics } & \multicolumn{2}{|c|}{ HBV DNA levels (IU/ml) } & \multirow[b]{2}{*}{ P-value } \\
\hline & $\leq 2,000$, no. $(\%)$ & $>2,000$, no. $(\%)$ & \\
\hline Age, years $($ mean \pm SEM) & $55.4 \pm 1.5$ & $55.0 \pm 1.5$ & 0.856 \\
\hline Age $>50$ years & $34(65.4)$ & $32(60.4)$ & 0.595 \\
\hline Male gender & $25(48.1)$ & $23(43.4)$ & 0.630 \\
\hline Diagnosis & & & 0.665 \\
\hline Breast cancer & $19(36.5)$ & $20(37.7)$ & \\
\hline Lung cancer & $11(21.2)$ & $8(15.1)$ & \\
\hline Colon cancer & $10(19.2)$ & $8(15.1)$ & \\
\hline Others & $12(23.1)$ & $17(32.1)$ & \\
\hline $\mathrm{HBsAg}>250 \mathrm{IU} / \mathrm{ml}$ & $13(25.0)$ & $38(71.7)$ & $<0.001$ \\
\hline Mean ALT & $29.8 \pm 3.5$ & $45.5 \pm 7.7$ & 0.069 \\
\hline Abnormal ALT & $10(19.2)$ & $19(35.8)$ & 0.057 \\
\hline AST, U/1 (mean \pm SEM) & $28.5 \pm 3.8$ & $42.8 \pm 9.1$ & 0.153 \\
\hline Total bilirubin, $\mathrm{mg} / \mathrm{dl}($ mean $\pm \mathrm{SEM})$ & $0.68 \pm 0.06$ & $0.93 \pm 0.29$ & 0.402 \\
\hline Creatinine, $\mathrm{mg} / \mathrm{dl}($ mean $\pm \mathrm{SEM})$ & $0.80 \pm 0.03$ & $0.76 \pm 0.03$ & 0.437 \\
\hline $\mathrm{WBC}$ count $/ \mathrm{mm}^{3}($ mean $\pm \mathrm{SEM})$ & $6984 \pm 444$ & $6886 \pm 377$ & 0.867 \\
\hline $\mathrm{Hgb}, \mathrm{g} / \mathrm{dl}($ mean $\pm \mathrm{SEM})$ & $12.13 \pm 0.28$ & $12.42 \pm 0.26$ & 0.445 \\
\hline PLT count $\mathrm{x} 1,000 / \mathrm{mm}^{3}($ mean \pm SEM $)$ & $245.4 \pm 11.8$ & $221.6 \pm 11.1$ & 0.070 \\
\hline
\end{tabular}

Bold print indicates statistical significance. HBV, hepatitis B virus; SEM, standard error of the mean; HBsAg, hepatitis B surface antigen; ALT, alanine aminotransferase; AST, aspartate aminotransferase; WBC, white blood cell; Hgb, hemoglobin; PLT, platelet.

prophylactic use of antivirals in preventing HBV reactivation by chemotherapy, were based on the use of lamivudine, the first nucleos(t)ide analogue approved for the treatment of hepatitis B. However, the emergence of resistance to lamivudine may lead to hepatitis flares, liver failure and death, negating the clinical benefit (20). Based on previous report, the incidence of lamivudine resistance was $\sim 14-32 \%$ after 1 year and $\sim 60-70 \%$ after 5 years of therapy for patients with CHB (20). Despite its prophylactic use, drug-resistant mutations and hepatitis flares have been reported in patients treated with lamivudine during immunosuppressive therapy $(18,30)$. Recently, a newer generation of oral antivirals with higher antiviral potency, such as entecavir and tenofovir, have become available. Studies on immunocompetent patients with $\mathrm{CHB}$ demonstrated that the cumulative incidence of antiviral resistance for naïve patients was $1.2 \%$ to entecavir and $0 \%$ to tenofovir up to 5 years $(31,32)$. A non-randomized study from China (33) demonstrated that prophylactic therapy with entecavir $(n=34)$ was associated with significantly lower rates of hepatitis (5.9 vs. $27.0 \%, \mathrm{P}=0.007)$, hepatitis $\mathrm{B}$ reactivation ( 0 vs. $12.4 \%, \mathrm{P}=0.024)$ and disruption of chemotherapy (5.9 vs. $20.2 \%, \mathrm{P}=0.042$ ) as compared with the lamivudine group $(n=89)$. Based on the results obtained from the present study, lamivudine may not be the optimal option for all patients and the aim of 'preventive use' cannot be applied to all enrolled subjects. In agreement with the 2009 AASLD CHB practice guideline (20), we suggest that individuals with positive HBsAg and high HBV DNA levels $(\geq 2,000 \mathrm{IU} / \mathrm{ml})$, and those who require long-term prophylaxis (i.e., $>12$ months), should be treated with more potent antiviral agents possessing a higher genetic barrier to resistance, such as entecavir or tenofovir. Tenofovir may be preferable in patients who have had prior exposure to lamivudine, whereas entecavir may be preferred in those with a risk of renal function deterioration.

Strong evidence currently supports that the prophylactic use of antivirals to prevent $\mathrm{HBV}$ reactivation after cancer chemotherapy is more effective compared with rescue or on-demand use $(6,14)$. However, data regarding the timepoint for antiviral agent discontinuation are very limited. A previous study demonstrated that high levels of serum HBV DNA $(\geq 2,000 \mathrm{IU} / \mathrm{ml}$ ) prior to chemotherapy was the most important predictor of HBV relapse after withdrawal of prophylactic antiviral therapy (34). Baseline HBV DNA level may be used as an important guide to determine the duration of antiviral therapy. According to the 2009 AASLD CHB practice guideline (20), patients with a baseline HBV DNA level $<2,000 \mathrm{IU} / \mathrm{ml}$ should continue treatment for 6 months after completion of chemotherapy. Prophylactic antiviral therapy should be continued until the therapeutic endpoint for $\mathrm{CHB}$ is achieved in patients who are $\mathrm{HBsAg}$-positive with a high viral $\operatorname{load}(\geq 2,000 \mathrm{IU} / \mathrm{ml})$ prior to the initiation of chemotherapy to reduce the risk of post-treatment relapse.

Since the identification of HBsAg by Blumberg in 1965, HBsAg has been used as a diagnostic marker for overt HBV infection (35). Automated quantitative assays for serum $\mathrm{HBsAg}$ have recently become available, facilitating standardized 
quantification of serum HBsAg level. This has led to increased interest in the clinical application of quantitative serum $\mathrm{HBsAg}$ levels for predicting therapeutic response $(36,37)$. Our present study demonstrated that quantitative HBsAg level was the only baseline factor associated with HBV DNA levels. A total of $74.5 \%$ of the patients with $\mathrm{HBsAg} \geq 250 \mathrm{IU} / \mathrm{ml}$ have $\mathrm{HBV}$ DNA levels $>2,000 \mathrm{IU} / \mathrm{ml}$, compared with $27.8 \%$ patients with HBsAg <250 IU/ml. Other clinical and demographic variables are not helpful in discriminating baseline virological activities prior to the initiation of cancer chemotherapy. In concordance with previous reports $(38,39)$, we observed a significant correlation between HBsAg and HBV DNA levels. Serum quantitative HBsAg levels at baseline may provide complementary information on virological activity if HBV DNA data are not available.

In summary, the key to the prevention of $\mathrm{HBV}$ reactivation is the identification of patients with $\mathrm{HBV}$ infection prior to initiation of cancer chemotherapy. We recommend universal screening in highly endemic areas, such as Taiwan, as no validated risk tools to identify HBV infection may be easily applied in clinical practice. We observed a wide distribution of baseline HBV DNA levels in CHB patients diagnosed with non-hematological malignancies. Of note, approximately half of the patients (i.e., those with HBV DNA >2,000 IU/ml) had a higher risk of $\mathrm{HBV}$ reactivation if no proper antiviral prophylaxis was undertaken. The selection of antiviral agents and the duration of therapy should be adjusted according to the baseline HBV replication status.

\section{Acknowledgements}

The present study was supported in part by grants from the Taipei Veterans General Hospital (V105C-068), Szu-Yuan Research Foundation of Internal Medicine (104-011) and Research Foundation of Digestive Medicine (104-10), Taiwan, R.O.C.

\section{References}

1. Lok AS, Liang RH, Chiu EK, Wong KL, Chan TK and Todd D: Reactivation of hepatitis B virus replication in patients receiving cytotoxic therapy. Report of a prospective study. Gastroenterology 100: 182-188, 1991.

2. Yeo W, Chan PK, Zhong S, Ho WM, Steinberg JL, Tam JS, Hui P, Leung NW, Zee B and Johnson PJ: Frequency of hepatitis B virus reactivation in cancer patients undergoing cytotoxic chemotherapy: A prospective study of 626 patients with identification of risk factors. J Med Virol 62: 299-307, 2000.

3. Yeo W and Johnson PJ: Diagnosis, prevention and management of hepatitis B virus reactivation during anticancer therapy. Hepatology 43: 209-220, 2006.

4. Loomba R, Rowley A, Wesley R, Liang TJ, Hoofnagle JH, Pucino F and Csako G: Systematic review: The effect of preventive lamivudine on hepatitis $\mathrm{B}$ reactivation during chemotherapy. Ann Intern Med 148: 519-528, 2008.

5. Hoofnagle JH: Reactivation of hepatitis B. Hepatology 49 (Suppl 5): S156-S165, 2009.

6. Hwang JP and Lok AS: Management of patients with hepatitis B who require immunosuppressive therapy. Nat Rev Gastroenterol Hepatol 11: 209-219, 2014.

7. Yeo W, Chan PK, Hui P, Ho WM, Lam KC, Kwan WH, Zhong S and Johnson PJ: Hepatitis B virus reactivation in breast cancer patients receiving cytotoxic chemotherapy: A prospective study. J Med Virol 70: 553-561, 2003

8. Yeo W, Zee B, Zhong S, Chan PK, Wong WL, Ho WM, Lam KC and Johnson PJ: Comprehensive analysis of risk factors associating with hepatitis $\mathrm{B}$ virus (HBV) reactivation in cancer patients undergoing cytotoxic chemotherapy. Br J Cancer 90: 1306-1311, 2004.
9. Cheng AL, Hsiung CA, Su IJ, Chen PJ, Chang MC, Tsao CJ, Kao WY, Uen WC, Hsu CH, Tien HF, et al: Steroid-free chemotherapy decreases risk of hepatitis B virus (HBV) reactivation in HBV-carriers with lymphoma. Hepatology 37: 1320-1328, 2003.

10. Yeo W, Chan TC, Leung NM, Lam WY, Mo FK, Chu MT, Chan HL, Hui EP, Lei KI, Mok TS and Chan PK: Hepatitis B virus reactivation in lymphoma patients with prior resolved hepatitis B undergoing anticancer therapy with or without rituximab. J Clin Oncol 27: 605-611, 2009.

11. Lau GK, Leung YH, Fong DY, Au WY, Kwong YL, Lie A, Hou JL, Wen YM, Nanj A and Liang R: High hepatitis B virus (HBV) DNA viral load as the most important risk factor for HBV reactivation in patients positive for HBV surface antigen undergoing autologous hematopoietic cell transplantation. Blood 99: 2324-2330, 2002.

12. Ohishi W and Chayama K: Prevention of hepatitis B virus reactivation in immunosuppressive therapy or chemotherapy. Clin Exp Nephrol 15: 634-640, 2011.

13. Hui CK, Cheung WW, Zhang HY, Au WY, Yueng YH, Leung AY, Leung N, Luk JM, Lie AK, Kwong YL, et al: Kinetics and risk of de novo hepatitis B infection in HBsAg-negative patients undergoing cytotoxic chemotherapy. Gastroenterology 131: 59-68, 2006.

14. Ferraro D, Pizzillo P, Di Marco V, Vultaggio A, Iannitto E, Venezia G, Craxi A and Di Stefano R: Evaluating the risk of hepatitis B reactivation in patients with haematological malignancies: Is the serum hepatitis B virus profile reliable? Liver Int 29: 1171-1177, 2009.

15. Lau GK, He ML, Fong DY, Bartholomeusz A, Au WY, Lie AK, Locarnini $\mathrm{S}$ and Liang R: Preemptive use of lamivudine reduces hepatitis B exacerbation after allogeneic hematopoietic cell transplantation. Hepatology 36: 702-709, 2002.

16. Lau GK, Yiu HH, Fong DY, Cheng HC, Au WY, Lai LS, Cheung M, Zhang HY, Lie A, Ngan R and Liang R: Early is superior to deferred preemptive lamivudine therapy for hepatitis B patients undergoing chemotherapy. Gastroenterology 125: 1742-1749, 2003.

17. Rossi G, Pelizzari A, Motta M and Puoti M: Primary prophylaxis with lamivudine of hepatitis $\mathrm{B}$ virus reactivation in chronic HBsAg carriers with lymphoid malignancies treated with chemotherapy. Br J Haematol 115: 58-62, 2001.

18. Chan TM, Fang GX, Tang CS, Cheng IK, Lai KN and Ho SK: Preemptive lamivudine therapy based on HBV DNA level in HBsAg-positive kidney allograft recipients. Hepatology 36: 1246-1252, 2002.

19. Hsu C, Hsiung CA, Su IJ, Hwang WS, Wang MC, Lin SF, Lin TH, Hsiao $\mathrm{HH}$, Young JH, Chang MC, et al: A revisit of prophylactic lamivudine for chemotherapy-associated hepatitis B reactivation in non-Hodgkin's lymphoma: A randomized trial. Hepatology 47: 844-853, 2008

20. Lok AS and McMahon B: AASLD practice guidelines chronic hepatitis B: Update 2009. Hepatology 50: 1-36, 2009.

21. Lou SC, Pearce SK, Lukaszewska TX, Taylor RE, Williams GT and Leary TP: An improved Abbott ARCHITECT assay for the detection of hepatitis B virus surface antigen (HBsAg). J Clin Virol 51: 59-63, 2011.

22. Chevaliez S, Bouvier-Alias M, Laperche S, Hézode C and Pawlotsky JM: Performance of version 2.0 of the Cobas AmpliPrep/Cobas TaqMan real-time PCR assay for hepatitis B virus DNA quantification. J Clin Microbiol 48: 3641-3647, 2010.

23. Tur-Kaspa R, Burk RD, Shaul Y and Shafritz DA: Hepatitis B virus DNA contains a glucocorticoid-responsive element. Proc Natl Acad Sci USA 83: 1627-1631, 1986.

24. Yun J, Kim JH, Kang ES, Gwak GY, Choi MS, Lee JE, Nam SJ, Yang JH, Park YH, Ahn JS and Im YH: Prophylactic use of lamivudine for hepatitis B exacerbation in post-operative breast cancer patients receiving anthracycline-based adjuvant chemotherapy. Br J Cancer 104: 559-563, 2011.

25. Yeo W and Chan HL: Hepatitis B virus reactivation associated with anti-neoplastic therapy. J Gastroenterol Hepatol 28: 31-37, 2013.

26. Hsu CH, Hsu HC, Chen HL, Gao M, Yeh PY, Chen PJ and Cheng AL: Doxorubicin activates hepatitis B virus (HBV) replication in HBV-harboring hepatoblastoma cells. A possible novel mechanism of $\mathrm{HBV}$ reactivation in $\mathrm{HBV}$ carriers receiving systemic chemotherapy. Anticancer Res 24: 3035-3040, 2004.

27. Weinbaum CM, Williams I, Mast EE, Wang SA, Finelli L, Wasley A, Neitzel SM and Ward JW; Centers for Disease Control and Prevention (CDC): Recommendations for identification and public health management of persons with chronic hepatitis $B$ virus infection. MMWR Recomm Rep 57: 1-20, 2008. 
28. European Association For The Study Of The Liver: EASL clinical practice guidelines: Management of chronic hepatitis B virus infection. J Hepatol 57: 167-185, 2012.

29. Liaw YF, Kao JH, Piratvisuth T, Chan HL, Chien RN, Liu CJ, Gane E, Locarnini S, Lim SG, Han KH, et al: Asian-Pacific consensus statement on the management of chronic hepatitis B: A 2012 update. Hepatol Int 6: 531-561, 2012.

30. Vassilopoulos D, Apostolopoulou A, Hadziyannis E, Papatheodoridis GV, Manolakopoulos S, Koskinas J, Manesis EK and Archimandritis AI: Long-term safety of anti-TNF treatment in patients with rheumatic diseases and chronic or resolved hepatitis B virus infection. Ann Rheum Dis 69: 1352-1355, 2010.

31. Marcellin P, Gane E, Buti M, Afdhal N, Sievert W, Jacobson IM, Washington MK, Germanidis G, Flaherty JF, Aguilar Schall R, et al: Regression of cirrhosis during treatment with tenofovir disoproxil fumarate for chronic hepatitis B: A 5-year open-label follow-up study. Lancet 381: 468-475, 2013.

32. Tenney DJ, Rose RE, Baldick CJ, Pokornowski KA, Eggers BJ, Fang J, Wichroski MJ, Xu D, Yang J, Wilber RB and Colonno RJ: Long-term monitoring shows hepatitis B virus resistance to entecavir in nucleoside-naïve patients is rare through 5 years of therapy. Hepatology 49: 1503-1514, 2009.

33. Li HR, Huang JJ, Guo HQ, Zhang X, Xie Y, Zhu HL, Zhai LZ $\mathrm{Pu}$ XX, Huang Y, Guo CC and Lin TY: Comparison of entecavir and lamivudine in preventing hepatitis $\mathrm{B}$ reactivation in lymphoma patients during chemotherapy. J Viral Hepat 18: $877-883,2011$.
34. Hui CK, Cheung WW, Au WY, Lie AK, Zhang HY, Yueng YH, Wong BC, Leung N, Kwong YL, Liang R and Lau GK: Hepatitis B reactivation after withdrawal of pre-emptive lamivudine in patients with haematological malignancy on completion of cytotoxic chemotherapy. Gut 54: 1597-1603, 2005.

35. Blumberg BS, Sutnick AI and London WT: Hepatitis and leukemia: Their relation to Australia antigen. Bull N Y Acad Med 44: 1566-1586, 1968.

36. Chan HL, Thompson A, Martinot-Peignoux M, Piratvisuth T, Cornberg M, Brunetto MR, Tillmann HL, Kao JH, Jia JD, Wedemeyer $\mathrm{H}$, et al: Hepatitis B surface antigen quantification: Why and how to use it in 2011 - a core group report. J Hepatol 55: 1121-1131, 2011.

37. Nguyen T, Desmond P and Locarnini S: The role of quantitative hepatitis B serology in the natural history and management of chronic hepatitis B. Hepatol Int 3 (Suppl 1): S5-S15, 2009.

38. Chen $\mathrm{CH}$, Lee CM, Wang JH, Tung HD, Hung CH and Lu SN: Correlation of quantitative assay of hepatitis B surface antigen and HBV DNA levels in asymptomatic hepatitis B virus carriers. Eur J Gastroenterol Hepatol 16: 1213-1218, 2004.

39. Chan HL, Wong VW, Tse AM, Tse CH, Chim AM, Chan HY, Wong GL and Sung JJ: Serum hepatitis B surface antigen quantitation can reflect hepatitis B virus in the liver and predict treatment response. Clin Gastroenterol Hepatol 5: 1462-1468, 2007. 